International Journal of

NASOPHARYNGEAL CARCINOMA

Journal homepage: ijnpc.usu.ac.id

\title{
COMPARISONS BETWEEN CYTOLOGICAL RESULTS FROM BRUSHING METHOD UNDER NASOPHARYNGOSCOPY GUIDANCE AND HISTOPATHOLOGICAL RESULTS FROM BLIND BIOPSY OF NASOPHARYNX IN NASOPHARYNGEAL CARCINOMA PATIENTS
}

\author{
Selvianti ${ }^{1 *}$, Irwan Kristyono ${ }^{1}$, Muhtarum Yusuf ${ }^{1}$ \\ ${ }^{1}$ Otorhinolaryngology Head and Neck Surgery Department Medical Faculty Airlangga University/Dr. Soetomo Hospital, Surabaya
}

\begin{abstract}
Introduction: Nasopharyngeal carcinoma (NPC) is one of the common head and neck malignancies found in Indonesia. Diagnosis was based on histopathological result of tumor tissues taken from the nasopharynx. Histopathological from nasopharyngeal blind biopsy remains a golden standard of NPC diagnosis. Blind biopsy causes many problems for patients including pain sensation, risk of bleeding and traumatic effect. Another technique for obtaining specimen for evaluation malignant cells of nasopharynx was by cytological investigation. Cytology evaluation could detect malignant cells from smear specimen. Cytological specimen could be obtained from nasopharynx by brushing method. Cells are collected by brushing then processed with liquid-based technique; specimens were smeared and stained for cytology evaluation. Since nasopharynx location is invisible, then nasopharyngoscopy guidance was used to obtain a brushing specimen.

Objective: To analyze an agreement between cytological results from nasopharyngeal brushing under nasopharyngoscopy and histopathological results from blind biopsy as a golden standard for the detection of malignant cells in NPC patients.

Method: Diagnostic test with the cross-sectional comparative study. Population of this study was NPC patients who came to outpatient Department of Otorhinolaryngology Head and Neck Surgery Dr. Soetomo Hospital Surabaya. Samples were collected with consecutive sampling method during February until May 2011. During that period we obtained 36 patients as study samples. First we performed brushing method under nasopharyngoscopy guidance and then blind biopsy of nasopharynx on each patient. Cytology preparation processed with liquid-based technique liquiPREP and Papanicolaou stain. Histopathologic preparation used hematoxylin and eosin (H\&E) stain. Sample data was tested by McNemar test and Kappa association test.

Result: 36 samples were obtained consisted of 27 male (75\%) and 9 female (25\%). The result for cytological evaluation in detecting malignant cells of NPC patients was sensitivity $87.10 \%$, specificity $80 \%$, positive predictive value $96.43 \%$, negative predictive value $50 \%$ and accuracy $86.11 \%$. Statistically, analysis result with McNemar test was no significant difference and from Kappa association test there was a significant association between brushing method under nasopharyngoscopy guidance and blind biopsy.

Conclusion: There was an agreement between brushing method under nasopharyngoscopy guidance and blind biopsy in detecting malignant cells of NPC.
\end{abstract}

\section{Article Info}

Keywords

Diagnostic test, nasopharyngeal carcinoma, brushing cytology

\section{*Corresponding author}

Address: J1. Mayjen Prof. Dr. Moestopo No.6-8, Airlangga, Kecamatan Gubeng, Kota Surabaya, Jawa Timur 60286, Indonesia

e-mail: selviantidr@yahoo.co.id

\section{INTRODUCTION}

Nasopharyngeal carcinoma (NPC) is a malignant tumor of the head and neck were mostly found in Indonesia [1,2]. New patients from the year 2000-2001 at outpatient Department of Otorhinolaryngology Head and Neck Surgery Dr. Soetomo Hospital Surabaya were 1037 patients. 623 of them $(67.72 \%)$ were NPC patients [2]. Early symptoms of NPC are not typical. Also it is difficult to see the location of the nasopharynx (hidden) so that patients coming for treatment are often already in advanced stages (III and IV). Diagnosis of NPC is established based on the histopathological result of tumor tissue taken from nasopharynx [3]. Histopathological examination is the gold standard for the diagnosis of NPC [4]. Success rate of this way in establishing a diagnosis of NPC is quite high, about $97.25 \%$, as quoted by Anwar, 2006. Taking of tumor tissue for histopathological examination is generally done by using a biopsy forceps blindly (Takahashi forceps or Blakesley) sometimes can cause pain and bleeding [5]. Diagnosis of cancer in addition to the histopathological examination can also be made in cytological. The principle of cytological examination is finding cancer/malignant cells from aspiration or smear material. One way to obtain a specimen transepithelial by performing brushing of the lesion [5].

Some of the advantages of cytology brushing are easy to work, non-invasive can reach a broader area, more epithelial cells were obtained, very minimal bleeding, almost no pain or minimal pain, and the results are faster and cheaper. Brushing material can be taken with the aid of endoscopy [6]. Preparation of specimens can be done with conventional smearing techniques or with liquid-based technique. The liquid-based technique is a new technique developed since the 1990s, which gives an advantage over conventional [7]. Nasopharyngoscopy can assist in taking the biopsy specimen or brushing specimen because of the hidden location of the nasopharynx. Biopsy techniques under nasopharyngoscopy guidance have often done as a standard procedure for NPC diagnosis especially in developed countries. For small or residual tumors, this technique is more accurate because of the sensitivity of $97 \%$ [8]. This study aims to analyze the agreement between cytological result from brushing method under nasopharyngoscopy guidance and histopathological result from a blind biopsy of nasopharynx as standard in determining the presence or absence of malignant cells in patients with NPC.

\section{MATERIAL AND METHODS}

This study is a diagnostic test observational analytic with a cross-sectional study design. The research was conducted from February to May 2011 in the outpatient Department of Otorhinolaryngology Head and Neck Surgery Dr. Soetomo Hospital Surabaya. The population of the study whereas suspected of NPC patients. Samples were taken from suspected NPC patients who came to the outpatient Department of Otorhinolaryngology Head and Neck Surgery Dr. Soetomo Hospital Surabaya and met the study criteria. Inclusion criteria include patients with clinically NPC that, cooperative and willing to participate in research. Exclusion criteria include patients that have impairment or disease in 
the nasal cavity such as polyps or septal deviation, which unable to perform nasopharyngoscopy, brushings and biopsy of the nasopharynx and also with poor general condition (Karnofsky scale $<40$ ).

The total sample of 36 patients, on every patient we perform nasopharyngeal brushings with nasopharyngoscope guide and blind biopsy of the nasopharynx.

Brushing material processed with liquid-based Liqui-PREPTM technique at Clinical Pathology Department Dr. Soetomo Hospital then sent to the Anatomy Pathology Department Dr. Soetomo Hospital for Papanicolaou smear and cytology examination by Anatomy Pathology specialist doctor. Biopsy tissue was sent to the Anatomy Pathology Department Dr. Soetomo Hospital for hematoxylin-eosin (HE) smear and histopathologic examination by Anatomy Pathology specialist doctor.

Data from cytology and histopathology was added to a data collection sheet and then processed statistically. The data were processed using a diagnostic test includes calculating the sensitivity, specificity, positive predictive value, negative predictive value, and accuracy. Furthermore, the comparison test McNemar and Kappa association test. The research hypothesis is there is an agreement between cytological result from brushing method under nasopharyngoscopy guidance and histopathological result from a blind biopsy of nasopharynx as a golden standard for the detection of malignant cells in NPC patients. Equivalence means there is no significant difference by comparison McNemar test $(p>0.05)$ and there is a significant relationship by Kappa based association test $(\mathrm{p}<0.05)$. This study was approved by the Health Research Ethics Committee of Dr. Soetomo Hospital.

\section{RESULT}

During the study period from February to May 2011, we obtained 36 patients who met the study criteria as samples. The youngest age of 16 years and the oldest 83 years old. A total of 27 patients (75\%) males and 9 patients $(25 \%)$ of women Most patients in the age group 41-50 year, 13 patients (36.11\%). Age group 51-60 years and above 60 years have the same number of lots that each of 8 patients $(22.22 \%)$, are second most patients.

Most histopathologic types found in this study is the NPC WHO type III, a total of 27 patients (75\%). Other histopathological types are WHO type I and type II only found in 4 patients $(11.11 \%)$. There are 5 patients $(13.89 \%)$ with no malignant cells in a blind biopsy histopathologic examination. Most people who become samples were stage IV, 30 patients $(83.33 \%)$. There are 2 patients at stage II $(5.56 \%), 4$ patients at stage III $(11.11 \%)$. Stage I was not found in this study.

Distribution of cytological result from brushing method under nasopharyngoscopy guidance by histopathological types of blind biopsy contained in Table 1. NPC WHO type I was found in 1 patient with positive cytology results (100\%). NPC WHO type II found in 3 patients, positive cytology results in 2 patients $(66.67 \%)$ and negative in 1 patient $(33.33 \%)$. At NPC WHO type III found in 27 patients, positive cytology results in 24 patients $(88.89 \%)$ and negative in 3 patients $(11.11 \%)$. From 36 samples there are 4 patients with both negative results from biopsy and cytology, although all these patients shown clinical signs and symptomns of NPC and met inclusion criteria.

Distribution of cytological result from brushing method under nasopharyngoscopy guidance based on clinical stage can be seen in Table 2 . There are one NPC stage II patients with positive cytology results. Stage III NPC were 2 patients, with positive cytology results in 1 patient $(50 \%)$ and negative in 1 patients $(50 \%)$. There were 29 stage IV NPC patients with positive cytology results in 25 patients $(86.20 \%)$ and negative in 4 patients $(13.80 \%)$.

Table 1. Distribution of the type of histopathology and cytology

\begin{tabular}{lrrr}
\hline \multicolumn{1}{c}{ Histopathology } & Cytology (+) & \multicolumn{1}{c}{ Cytology (-) } & \multicolumn{1}{c}{ Total } \\
\hline WHO type I & $1(100 \%)$ & $0(0 \%)$ & $1(100 \%)$ \\
WHO type II & $2(66.67 \%)$ & $1(33.33 \%)$ & $3(100 \%)$ \\
WHO type III & $24(88.89 \%)$ & $3(11.11 \%)$ & $27(100 \%)$ \\
Malignancy (-) & $1(20 \%)$ & $4(80 \%)$ & $5(100 \%)$ \\
\hline Total & $\mathbf{2 8 ( 7 7 . 7 8 \% )}$ & $\mathbf{8 ( 2 2 . 2 2 \% )}$ & $\mathbf{3 6 ( 1 0 0 \% )}$ \\
\hline
\end{tabular}

Table 2. Distribution based on clinical stage and cytologic brushings

\begin{tabular}{lrrr}
\hline \multicolumn{1}{c}{ NPC Stadium } & \multicolumn{1}{c}{ Cytology (+) } & \multicolumn{1}{c}{ Cytology (-) } & \multicolumn{1}{c}{ Total } \\
\hline Stage I & $0(0 \%)$ & $0(0 \%)$ & $0(0 \%)$ \\
Stage II & $2(100 \%)$ & $0(0 \%)$ & $2(100 \%)$ \\
Stage III & $1(25 \%)$ & $3(75 \%)$ & $4(100 \%)$ \\
Stage IV & $25(83.33 \%)$ & $5(16.67 \%)$ & $30(100 \%)$ \\
\hline Total & $\mathbf{2 8 ( 7 7 . 7 8 \% )}$ & $\mathbf{8 ( 2 2 . 2 2 \% )}$ & $\mathbf{3 6 ( 1 0 0 \% )}$ \\
\hline
\end{tabular}

From blind biopsy histopathologic examination, 31 patients $(86.11 \%)$ positive NPC at the first biopsy and 5 patients $(13.89 \%)$ negative. In cytological result from brushing method under nasopharyngoscopy guidance, 28 patients (77.78\%) positive malignant cells and 8 patients $(22.22 \%)$ negative malignant cells. The results of cytological result from brushing method under nasopharyngoscopy guidance and blind histopathological biopsy was put in the $2 \times 2$ table as shown in Table 3. As the result in table 3, there are 4 patients with both negative of biopsy and cytology concluded as non NPC patients.

Table 3. The results of brush cytology with nasopharyngoscopy guidance and histopathology blind biopsy

\begin{tabular}{lccc}
\hline & Biopsy (+) & Biopsy (-) & total \\
\hline Brush cytology (+) & 27 & 1 & 28 \\
Brush cytology (-) & 4 & 4 & 8 \\
\hline Total & $\mathbf{3 1}$ & $\mathbf{5}$ & $\mathbf{3 6}$ \\
\hline
\end{tabular}

Calculation and results based on data from Table 3 are sensitivity $87.10 \%$, specificity $80 \%$, positive predictive value $96.43 \%$, and negative predictive value $50 \%$ accuracy $86.11 \%$. Further statistical analysis using comparative test McNemar and Kappa association test. To compare the diagnostic accuracy of cytological result from brushing method under nasopharyngoscopy guidance using the McNemar test, $\mathrm{p}=0.375$. Means, between the results of cytological result from brushing method under nasopharyngoscopy guidance and blind biopsies, obtained no significant difference $(\mathrm{p}>0.05)$ as shown in table 4 . To determine the relationship between cytological result from brushing method under nasopharyngoscopy guidance and blind histopathological biopsy, we used Kappa association test and obtained the value of $p=0.001$. Means, between cytological result from brushing method under nasopharyngoscopy guidance and blind biopsies there is a significant relationship $(\mathrm{p}<0.05)$.

\section{DISCUSSION}

This observational study is a diagnostic test using a comparative crosssectional study design for researchers who wish to compare the results of cytologic result from brushing method under nasopharyngoscopy guidance with blind histopathologic biopsy. In order to obtain a good test result we needed a gold standard as a comparison. The clinical diagnostic test was assessed by comparing the test results in the $2 \times 2$ table (crosstabs). Assessment of the diagnostic test as a tool from the resulting value expressed in the sensitivity, specificity and predictive value [9]

The research was conducted from February to May 2011 and obtained 36 samples of patients with nasopharyngeal carcinoma. The sample was taken by the consecutive sampling means that every new patient with suspected NPC was coming for treatment at outpatient Department of Otorhinolaryngology Head and Neck Surgery Dr. Soetomo Hospital Surabaya and met the study criteria included as a sample. This technique is a type of non-probability sampling, often the best and easiest way [10].

This study aims to prove the validity of the hypothesis that there is an agreement between cytological result from brushing method under nasopharyngoscopy guidance and histopathological result from a blind biopsy of nasopharynx as the golden standard for the detection of malignant cells in NPC patients. This comparative study wanted to test the hypothesis that in between the two modes of the investigation there is no significant difference $(\mathrm{p}>0.05)$ and there is a correlation $(p<0.05)$. The reason researchers wanted to test the brushing method under nasopharyngoscopy guidance is that brush method more comfortable with a smaller risk of profuse bleeding and nasopharyngoscopy guidance will help obtain a specimen with a more focused.

From 36 patients entering the study, we found men more than women by a ratio of $3: 1$. The ratio of NPC incidence is higher in men than women by a ratio of about 2-3 versus 1 [11-13]. Number of NPC in men suspected because of the risk of contact with EBV more in men than women [11-13]. Number of patients by age group 41-50 years are $36.11 \%$. Azwar study (2006) also found the highest incidence of NPC in the age group 41-50 years in the amount of $31.43 \%$. NPC distribution pattern based on endemic and non-endemic areas. Endemic regions such as some parts of Asia, including Indonesia, has a distribution pattern of incidence increases with age and most of the incidents of NPC found in the fifth decade. Such nonendemic regions in Africa have a different distribution pattern incident that occurred two peaks of incidence or bimodal graph. The highlight major events in the age group of 50 years and a minor in the age group between 10 to 25 years [11].

Most histopathological type is type III WHO by $75 \%$. Other histopathological types are WHO type II at $8.33 \%$ and type I $2.78 \%$. In $13.89 \%$ of patients did not reveal any malignant cells by histopathologic blind biopsy results of the first manner. However, patients with clinical symptoms triad of NPC so still meet the criteria. Histopathological results found no malignant cells in the first blind biopsy can be influenced by several factors. Nasopharyngeal tumors that were not located in a predilection area as in general (such as on the roof of nasopharynx and lateral of fossa Rosenmuller) may cause failed to obtain malignant tissue by blind biopsy. Nasopharyngeal tumors located submucosa may also cause forceps failed to reach the tumor. Nasopharyngoscopy can help in this condition for visualization tumor so biopsy forceps can reach the tumor. 
In Indonesia, the most frequent type is NPC WHO type III. Research by Azwar, 2006, in Surabaya also did not find the type of NPC WHO type I, type II only (5.71\%) and type III (94.29\%) [5]. Research by Odi, 2007, only found NPC WHO type III on all patients who become samples [14]. Samples result from other researchers also shown similar histopathological distribution $[15,16]$. Majority are NPC WHO type III because the main cause of NPC has suspected EBV infection where NPC that associated with EBV is undifferentiated (WHO type III) and non-keratinizing (WHO type II) [17].

Table 1 shows the distribution of cytologic brushings divided by histopathologic type. At NPC WHO type I in 1 patient, positive cytology results found malignant cells in this patient. At NPC WHO type II as many as three patients, cytology was positive in 2 patients $(66.67 \%)$ and negative in 1 patien $(33.33 \%)$. For NPC WHO type III, of 24 patients $(88.89 \%)$ from 27 patients showed positive of malignant cells. In contrast to histopathologic biopsy that can differentiate the histopathologic type of NPC, then cytology brushings only show the presence or absence of malignant cells in the nasopharynx.

Four patients with negative cytology results, from nasopharyngoscopy only shown mucosal protrusion. Histopathological results of four patients were no malignancy. After a repeated biopsy, we obtained malignancy though patients not included in the research. Special in one patient with the histopathologic possibility of inflammation granulomatik tuberculosis, further evaluation needed. If it was stand-alone nasopharyngeal tuberculosis as a differential diagnosis or NPC together with nasopharyngeal tuberculosis, three patients with negative cytologic brush revealed nasopharyngeal mass filled with exophytic ulcerative necrotic tissue on the tumor surface. Malignant positive histopathological found in these patients. One patient with cytologic brush negative but positive histopathologic shown form of protrusion nasopharyngeal mucosa. The histopathologic result indicates NPC WHO type II.

The nasopharyngeal brush has limitation for tumor covered with necrotic tissue on its surface and also for submucosal tumor. Biopsy still the best choice because forceps can reach deeper tissue. Most of NPC masses are exophytic, ulcerative and fragile. Usually, there are loosely bound between malignant cells and between malignant and normal cells, so cells are easily detached when brushing applied and give positive cytologic results. Nasopharyngoscopy helps to point brushes to reach the tumor surface. Although this study showed the weakness of brush, most of NPC tumors are exophytic and ulcerative so brush still can give more benefits.

A total of 34 from 36 NPC patients in this study was found at an advanced stage (III and IV), even 30 patients $(83.33 \%$ ) had stage IV. This is consistent with research by Healtho, 2001, at Dr. Sardjito Hospital who found $86.36 \%$ of NPC patients at stage research IV [16]. Hadi, 1998, also found NPC patients with stage IV by $84.44 \%$ [18]. Research by Azwar 2006, getting a lower number, $62.86 \%$ in stage IV [5].

NPC staging in this study is based on clinical examination and endoscopy. Clinical staging is done before the brush and biopsy. The more accurate determination can use CT scanning, but due to limited funds and time then CT-scan was not performed. The main complaint which brings patients to come for treatment is a lump in the neck or neck mass-a total of 30 patients $(83.33 \%)$ of the 36 samples present with a neck lump. Additional complaints are ear complaints in 35 patients $(97.22 \%)$ but often overlooked because not harmful. There are nose complaints in 30 patients $(83.33 \%)$ and throat complaints in 24 patients $(66.67 \%)$. These findings are not much different from other studies before [5, 16, 18]. From clinical examination also found cranial nerves paralyzes (T4) in $32(88.89 \%)$.

From nasophayngoscope in 36 patients, the nasopharyngeal mass was found in 34 patients $(94.44 \%)$, while in 2 patients $(5.56 \%)$ only found mucosal thickening at Rossenmuller fossa. Of the two patients with mucosal thickening, 1 patient gives a positive cytologic result with negative histopathologic and 1 patient with a negative cytologic result with positive histopathologic.

Table 2 shows the distribution of cytologic brushings based on clinical stage of NPC. Two patients with stage II showed positive cytology results (100\%). From these patients, 1 patient with positive histopathologic whereas 1 patient with negative histopathologic. It requires consideration if this is a false positive for the brush or a false negative for blind biopsy. Does this mean the brush has the ability to reach a wider surface and nasopharyngoscopy can assist in directing the brush, of course, and need further investigation. A negative histopathologic result of blind biopsy does not free the patient from NPC possibility directly but need to repeat the biopsy with nasopharyngoscopy guidance. In 4 patients with stage III, positive cytologic results in 1 patient $(25 \%)$ and negative in 3 patients $(75 \%)$. Of the four patients, one patient with positive cytologic also showed positive histopathologic, whereas 3 patients with negative cytologic at histopathologic examination also showed negative results. From 30 stage IV patients, positive cytologic results found in 25 patients $(83.33 \%)$ and negative in 5 patients $(16.67 \%)$.

Study for the effectiveness of cytologic brushings based on clinical stage of NPC, especially for stage I, II and III is still necessary since the number of samples for these stadium is not enough. Unfortunately, most patients come at stage IV disease, so study on early stage is not easy. Another alternative is screening and early detection research for communities with a high incidence of NPC or high-risk groups.
In cytologic brushing under nasopharyngoscope guidance of 36 patients obtained positive malignant cells results in 28 patients $(77.78 \%)$ and negative results in 8 patients $(22.22 \%)$ as shown in table 3 . These results are higher than the results obtained by Azwar 2006, positive malignant cells $71.43 \%$ and negative $28.57 \%$ [5]. Healtho study in 2001, obtained a positive result in $68.33 \%$ of 60 samples [16]. Chang et al. study, 2001, obtained positive cytologic results in 103 patients $(69.1 \%)$ of 149 penderita [19].

Concurrent validity refers to the extent, which a measuring instrument correlates with the gold standard at the same time, can be assessed by a measure of sensitivity and specificity. Differences in sensitivity and specificity value may be influenced by tools, skills, specimen processing, and results reading. To reduce bias of this study, numbers of things have been uninformed include tools, research skill, specimen processing techniques and results reading.

The sensitivity of cytologic brushing under nasopharyngoscopy guidance in this study amounted to $87.10 \%$, which means this technique has an accuracy of detecting malignant cells in the nasopharynx of $87.10 \%$. False negative of this method is $12.90 \%$, means there are $12.90 \%$ of NPC patients not detected by this technique. Specificity of this study is $80 \%$, means this method can eliminate the possibility of not suffering from NPC in patients who are not sick by $80 \%$. Falsepositive results are $20 \%$ ( 1 patient) showed that $20 \%$ of patients who are not sick have the possibility detected as positive with this technique. Several other studies have obtained results that were not much different $[5,16,19]$.

The specimens obtained then processed with liquid-based technique. The advantage of this technique is that it can remove almost all confounding cells such as erythrocytes so that a homogeneous specimen will be obtained which only consists of squamous epithelial cells and lymphocyte cells.

The positive predictive value in this study amounted to $96.43 \%$ and negative predictive value in this study amounted to $50 \%$. Accuracy value of this study is $86.11 \%$, means in comparison with blind histopathologic biopsy, cytologic brushing by nasopharyngoscopy guidance has truth rate of $86.11 \%$. Several other studies have varied results $[5,16,19]$.

Research by Chang et al., 2001, in Hong Kong on 528 study subjects obtained a sensitivity value of $69.1 \%$ and a specificity of $100 \% .19$ Research by Jan et al. (2009) in Taiwan on 48 patients for NPC diagnosis also with cytologic brushing under nasopharyngoscopy guidance, the results obtained sensitivity value of $84.2 \%$, specificity value $96.6 \%$ and accuracy $93.6 \%$ [7].

In case to prove the equivalence between cytological result from brushing method under nasopharyngoscopy guidance and blind histopathological biopsy, McNemar comparative tests and Kappa association tests were carried out. McNemar comparative test results obtained a value of $\mathrm{p}=0.375$, which means there is no significant difference $(\mathrm{p}>0.05)$. Kappa association test results obtained a value of $\mathrm{p}=0.001$, which means there is a significant relationship $(\mathrm{p}<0.05)$.

\section{CONCLUSION}

From this study, it could be concluded that there is an agreement between cytological result from brushing method under nasopharyngoscopy guidance and histopathological result from a blind biopsy of the nasopharynx in determining the presence or absence of malignant cells in patients with NPC.

\section{REFERENCE}

[1] Roezin A, Adham M. Karsinoma Nasofaring, dalam Buku Ajar THT commit to user FKUI. Jakarta, hal; 2007.

[2] Soekamto S, Sandhika W, Fauziah D. Aspek patologi tumor telinga hidung tenggorok-kepala leher: perkembangan terkini diagnosis dan penatalaksanaan tumor ganas THT-KL. Surabaya: SMF Ilmu Penyakit THT-KL FK Unair/RSUD Dr Soetomo Surabaya. 2002:9-37.

[3] Stanley R, Fong K. Clinical presentation and diagnosis. Nasopharyngeal Carcinoma Singapore, Armour. 1997.

[4] Kentjono W. Pengaruh vaksinasi BCG dalam meningkatkan respon T Helper 1 (Th1) dan respon tumor terhadap radiasi pada karsinoma nasofaring. Disertasi Program Pascasarjana Universitas Airlangga, Surabaya. 2001.

[5] Azwar A. Perbandingan Antara Hasil Pemeriksaan Sitologi Sikatan dan Biopsi Buta pada Penderita Karsinoma Nasofaring. Jurnal Kedokteran Syiah Kuala. 2010;10(3):137-44.

[6] EK A, KR P, KS M, al e. Role of diagnostic cytology. In: Varghese C, Venkataraman K, Bhagwat S eds. Manual for cytology. 2005(November 2005):9-14.

[7] Jan Y-J, Chen S-J, Wang J, Jiang R-S. Liquid-based cytology in diagnosing nasopharyngeal carcinoma. American journal of rhinology \& allergy. 2009;23(4):422-5

[8] Kentjono W. Karsinoma nasofaring: etiologi, gejala, diagnosis, deteksi dini, terapi dan pencegahan. Pelatihan Deteksi Dini Kanker Nasofaring untuk Dokter Umum di Puskesmas, Surabaya, Dept/SMF Ilmu Kesehatan THT-KL FK Unair/RSUD Dr Soetomo. 2010:13-41.

[9] P S, EP S, J S. Epidemiologi klinis. 1998:21-48. 
[10] Pusponegoro H, Wirya I, Pudjiadi A, Bisanto J, Zulkarnain S. Uji diagnostik. Dasar-dasar metodologi penelitian klinis 2nd ed Jakarta: Sagung Seto. 2002:166-84.

[11] Spano J-P, Busson P, Atlan D, Bourhis J, Pignon J-P, Esteban C, et al. Nasopharyngeal carcinomas: an update. European journal of cancer. 2003;39(15):2121-35

[12] CHEW CT. Nasopharynx (the postnasal space). Chapter 19. Scott-Brown's OtOlaryngology 5th ed, Vol4 M ckay IS, Bull T Reds. 1987:330-4.

[13] KS C, HP L. Epidemiology. In: Chong VJH, Tsao SY, eds. Nasopharyngeal carcinoma. 1997:29-35.

[14] KH O. Perbandingan Hasil Pemeriksaan Biopsi dengan Tuntunan Nasofaringoskopi dan Biopsi Buta dalam Menegakkan Diagnosis Karsinoma Nasofaring. 2007:55.

[15] Soetjipto D. Karsinoma nasofaring. Tumor Telinga Hidung dan Tenggorok Diagnosis dan Penatalaksanaannya, Jakarta, Fakultas Kedokteran Univesitas Indonesia. 1989:71-83.

[16] DAHLIA HL, Bambang Hariwiyanto S. Metoda penyikatan pada deteksi keganasan nasofarings: [Yogyakarta]: Universitas Gadjah Mada; 2002.

[17] R P. Pathology. In: Chong VJH, Tsao SY, eds. Nasopharyngeal carcinoma. 1997:6-13.

[18] W H. Aspek klinis dan histopatologi karsinoma nasofaring di Lab/SMF THT FK Unair/RSU Dr Soetomo Surabaya tahun 1997. 1998.

[19] Chang AR, Liang XM, Chan AT, Chan MK, Teo PM, Johnson PJ. The use of brush cytology and directed biopsies for the detection of nasopharyngeal carcinoma and precursor lesions. Head \& neck. 2001;23(8):637-45. 